\title{
Survei Kesiapan Orang Tua dalam Mendampingi Proses Pembelajaran Anak Usia Dini Berbasis Daring
}

\author{
Ni Kadek Rista Ariswari ${ }^{*}$, Luh Ayu Tirtayani2 \\ 1,2 Pendidikan Guru Pendidikan Anak Usia Dini, Universitas Pendidikan Ganesha, Sinagaraja, Indonesia
}

\section{ART I CLE I N F O}

Article history:

Received 15 January 2021

Revised 04 February 2021

Accepted 01 April 2021

Available online 29 April 2021

Kata Kunci:

Kesiapan, Orang Tua,

Pembelajaran Daring

Keywords:

Readiness, Parents, Online

Learning

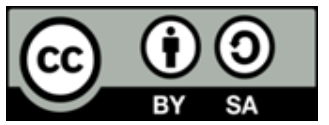

This is an open access article under the CC BY-SA license.

Copyright $($ C Universitas Pendidikan Ganesha. All rights reserved.

\begin{abstract}
A B S T R A K
Kondisi pandemi COVID-19 menyebabkan adanya kebijakan belajar dari rumah oleh pemerintah untuk mengurangi penyebaran virus. Sistem pembelajaran secara daring merupakan solusi ditengah pandemi dalam hal belajar mengajar dengan menggunakan aplikasi seperti Whatsapp grup, Google meet dan Zoom yang dapat membantu proses pendidikan dan pembelajaran berlangsung meskipun jaraknya jauh. Persiapan para orang tua memegang peranan penting sebagai bantuan dan sekaligus penyemangat bagi anak-anaknya ketika pulang kerumah. Dilakukannya riset ini guna menganalisa persiapan orang tua pada pembelajaran anak usia dini berbasis online. Jenis penelitian ini merupakan penelitian gambaran umum yang memukau dengan metodologi kuantitatif. Responden dalam penelitian adalah orang tua dalam kegiatan pembelajaran remaja berbasis daring sebanyak 390 responden. Teknik riset yang akan digunakan adalah clear investigation. Hasil dari riset ini diperoleh bahwa persiapan yang sebenarnya menunjukkan bahwa status orang tua dalam ukuran pembelajaran berbasis daring untuk remaja ditanggapi secara empatik oleh semua orang tua. Kesiapan orang tua dalam proses pembelajaran daring untuk remaja sejauh persiapan mental ditanggapi secara empatik. Persiapan orang tua dalam pembelajaran berbasis daring mengukur sejauh status materi ditanggapi secara empatik. Sejalan dengan itu, ditarik kesimpulan persiapan orang tua dalam langkah mendidik anak usia dini berbasis daring/online selama pandemi virus Corona disikapi dengan tegas.
\end{abstract}

\begin{abstract}
A B S T R A C T
The Coronavirus pandemic has prompted an examination from home approach by the public authority to lessen the spread of the infection. The internet learning framework is an answer amidst a pandemic as far as educating and learning by utilizing applications, for example, Whatsapp gatherings, Google meet and zoom which can help the instructing and learning measure proceed despite the fact that it is distantly. The availability of guardians assumes a significant part as an aide and simultaneously a spark for their kids when gaining from home. The reason for this examination is to investigate the preparation of guardians in the online-based youth learning measure. This sort of exploration is an engaging review research with a quantitative methodology. Respondents in this investigation were guardians in the online-based youth learning measure upwards of 390 respondents. The exploration technique that will be utilized is clear investigation. The aftereffects of this investigation got that actual status showed that the preparation of guardians in the online based learning measure for youth was reacted emphatically by all guardians. The status of guardians in the online based learning measure for youth as far as mental availability was reacted emphatically. The preparation of guardians in the internet learning measure as far as material availability was reacted decidedly. Subsequently, it was inferred that the preparation of guardians in the online-based youth learning measure during the Coronavirus pandemic was responded positively.
\end{abstract}




\section{Pendahuluan}

Indonesia adalah salah satu negara yang terkena dampak pandemi covid-19 yang mengharuskan pemerintah untuk membatasi setiap kegiatan di berbagai sektor termasuk pendidikan dengan melakukan kegiatan pembelajaran secara daring (Lilawati, 2020; Mansyur, 2020; Robandi \& Mudjiran, 2020). Kebijakan tersebut sesuai dengan Surat Edaran Nomor 15 Tahun 2020 yang menyebutkan bahwa tujuan dilakukannya Belajar Dari Rumah adalah untuk memenuhi pemenuhan hak seluruh peserta didik untuk mendapatkan layanan pendidikan dalam situasi pandemi dengan tetap melindungi peserta didik dari dampak covid 19 (Wijayanti \& Fauziah, 2020a, 2020b). UNESCO mengatakan bahwa 300 juta murid terganggu kegiatan pembelajarannya dan ratusan sekolah di Indonesia ditutup untuk sementara akibat dari virus COVID-19 (Widyasari, Nurbaiti., Irawan, Bambang., Muzayana, 2020) Kegiatan proses belajar mengajar dari rumah secara daring dilakukan dari tingkat TK sampai Universitas, yang tentunya peran orang tua sangat diperlukan untuk membantu proses pembelajaran tersebut bagi anak-anak yang belum bisa belajar secara mandiri. Bahwa orang tua melakukan dua peran sekaligus yaitu sebagai orang tua dan sebagai guru di rumah dalam membantu putra putri mereka yang bersekolah (Lilawati, 2020; Yulianingsih et al., 2020). Beberapa faktor yang yang mempengaruhi kesulitan orang tua diantaranya adalah latar belakang pendidikan yang mempengaruhi orang tua dalam mendidik anak, kondisi ekonomi yang dapat memberikan fasilitas anak dalam belajar daring, pengaturan waktu antara pekerjaan dan membantu anak belajar serta jumlah keluarga yang berada di rumah mempengaruhi orang tua dalam membimbing anak (Ota et al., 2021; Wardani \& Ayriza, 2020). Kegiatan belajar mengajar selanjutnya dilakukan secara daring dari berbagai tingkat pendidikan. belajar dirumah Bukan berarti memberikan banyak tugas kepada siswa, tetapi memunculkan pengajaran dan pembelajaran yang efisien sesuai dengan keadaan bidang masingmasing (Nur Khalimah, 2020)

Sekolah online berarti bahwa siswa melakukan pembelajaran dari rumah yang biasanya dilakukan disekolah, yang tentunya sangat membutuhkan bantuan orang tua dalam menerima setiap materi yang diberikan oleh guru (Jayawardana, 2020; Nurdin \& Anhusadar, 2020). Tidak semua siswa mampu menyerap materi dengan baik, maka orang tua harus bisa mengatur waktu untuk mendampingi anak, menerapkan kedisiplinan dan mengetahui mood anak. Peran orang tua dalam mendampingi anak selama belajar secara online sangat berpengaruh bagi anak (Kurniati et al., 2020; Nur Khalimah, 2020). Apabila orang tua mengalami kesulitan dalam membantu proses pembelajaran, orang tua yang tidak putus asa akan mencari solusi agar proses pembelajaran secara online dapat diserap anaknya dengan baik dan orang tua akan memberikan bekal kepada anak-anak mereka yang memang belum paham tentang pandemi yang mewabah untuk tetap di rumah agar agar tidak tercemar dan menularkan penyakit pandemi ini (Handayani, 2020). Masing-masing orang tua memiliki tingkat kesulitan yang berbeda-beda dalam mendampingi anak-anaknya. Apabila orang tua tersebut memiliki keterbatasan pendidikan, akan kesulitan dalam membantu anaknya dalam menerima materi pembelajaran. Bila orang tua memiliki keterbatasan dalam hal ekonomi maka akan kesulitan memberikan sarana penunjang anaknya dalam belajar online (Al Hakim, 2021; Handayani, 2020). Terdapat kendala secara umum yang dihadapi orang tua dalam pendampingan, diantaranya kemampuan pemahaman materi pembelajaran oleh orang tua, kesibukan pekerjaan, kurang sabarnya orang tua, pengoperasian gadget yang kurang mahir, jangkauan internet yang kurang serta orang tua tidak mampu memotivasi anak untuk belajar dari rumah dan orang tua kurang mengetahui mengenai aplikasi-aplikasi yang akan digunakan untuk pembelajaran daring ini seperti Whatsapp gathering, Google meet dan Zoom yang dapat membantu proses pendidikan dan pembelajaran berlangsung. walaupun jaraknya jauh (Wardani \& Ayriza, 2020)

Dalam proses pembelajaran online, orang tua berperan dalam membantu guru di sekolah yaitu memotivasi anak dalam segala hal (Marom, 2020; Wisnu Budi Wijaya, 2019). Peran orang tua bukan sebagai pengganti guru namun membantu guru untuk selalu memonitoring, membuat anak fokus saat proses pembelajaran online, memberikan solusi kepada anak, dan mampu menguasai materi pembelajaran dari sekolah (Lilawati, 2020; Yulianingsih et al., 2020). Pembelajaran daring memiliki beberapa hambatan yang kurang layak, seperti pemberian tugas belajar oleh pendidik, melalui aplikasi yang akan disesuaikan oleh pengajar kepada anak melalui pembelajaran berbasis daring, ini merupakan ujian lain bagi orang tua untuk mengetahui pelaksanaan tugas untuk disebarkan oleh pendidik jadi interaksi belajar dapat diselesaikan (Syafari \& Montessori, 2020; Widyastuti et al., 2021). Pembelajaran berlangsung, namun sebagian besar orang tua menghadapi tantangan guna memahami tugas dari para pendidik, sehingga orang tua akan mendapatkan beberapa informasi tentang pelaksanaan pembelajaran oleh pendidik sehingga orang tua dapat memahami dan orang tua siap untuk menyampaikan kepada anak-anak tentang tugas-tugas pembelajaran yang diberikan oleh guru (Yusuf, 2020). Orang tua tidak hanya berperan dalam mendampingi anak dalam proses pembelajaran secara online, namun memberikan fasilitas penunjang pembelajaran online dan memberikan motivasi kepada anak-anak mereka dalam menerima pembelajaran dengan perasaan senang sehingga setiap tugas yang diberikan dapat diselesaikan 
dengan baik (Nurhasanah R, 2020). Peran orang tua selama anak melakukan pembelajaran secara online tidak sebatas hanya sebagau orang tua bagi anak-anaknya, namun kini berperan sebagai pendidik, pembimbing dalam pembelajaran berbasis daring lebih banyak dibawa oleh ketersediaan orang tua untuk menjadi pendidik di rumah. Orang tua diperlukan untuk menangani kebutuhan adaptasi berbasis daring anak-anak di rumah, hasilnya adalah pengaturan pemberian perangkat, laptop, atau perangkat lainnya kepada anak-anak biaya tambahan untuk membeli paket internet (Khasanah, 2021)

Beberapa hasil penelitian menyebutkan orang tua mengalami beberapa hambatan dalam mendampingi anak dalam proses pembelajaran online, namun proses pembelajaran online adalah kegiatan pembelajaran yang harus dilakukan selama masa pandemi belum berakhir maka dalam hal ini kesiapan orang tua dalam menghadapi pandemi diperlukan sehingga orang tua pun siap untuk mendampingi anak-anaknya untuk tetap menerima pendidikan walaupun secara online (Satriana et al., 2021; Yulianingsih et al., 2020). Orang tua harus siap menghadapi pandemi sehingga saat proses pembelajaran dilakukan secara online maka kerja sama orang tua sangat diperlukan dan kesiapan orang tua dalam mengendalikan diri juga penting sebelum mendampingi anak belajar, selanjutnya orang tua dapat memberikan pembelajaran tambahan yaitu akhlaq akidah dan ibadah, serta orang tua dapat menghilangkan rasa jenuh yang timbul dari proses pembelajaran secara online. Orang tua yaitu pendidik pertama serta berkelanjutan terhadap anak-anak mereka. Penelitian juga sudah mengungkapkan jika kualitas guru, termasuk standar serta pelatihan di dalam keterlibatan orang tua, sangat penting guna membantu keterlibatan dari orang tua agar lebih efektif. Dianggap luas, keterlibatan orang tua sendiri terdiri atas beberapa kemitraan antara lain keluarga, sekolah serta masyarakat, memaksimalkan kesadaran orang tua mengenai manfaat dalam keterlibatan di dalam pendidikan anak-anak belajar dirumah (ZULFIKAR, 2020). Tujuan dalam penelitian ini yaitu menganalisis kesiapan orang tua pada proses pengajaran anak usia dini berbasis daring berdasarkan aspek dimensi kesiapan fisik, psikis, dan materil.

\section{Metode}

Jenis penelitian ini adalah eksplorasi kuantitatif. Tinjauan adalah suatu eksplorasi yang diarahkan untuk mengkaji kondisi, kondisi, atau hal-hal lain yang telah diacu, kemudian hasil-hasilnya diperkenalkan sebagai laporan pemeriksaan (Arikunto, 2010). Berikut rencana pemeriksaan ini:

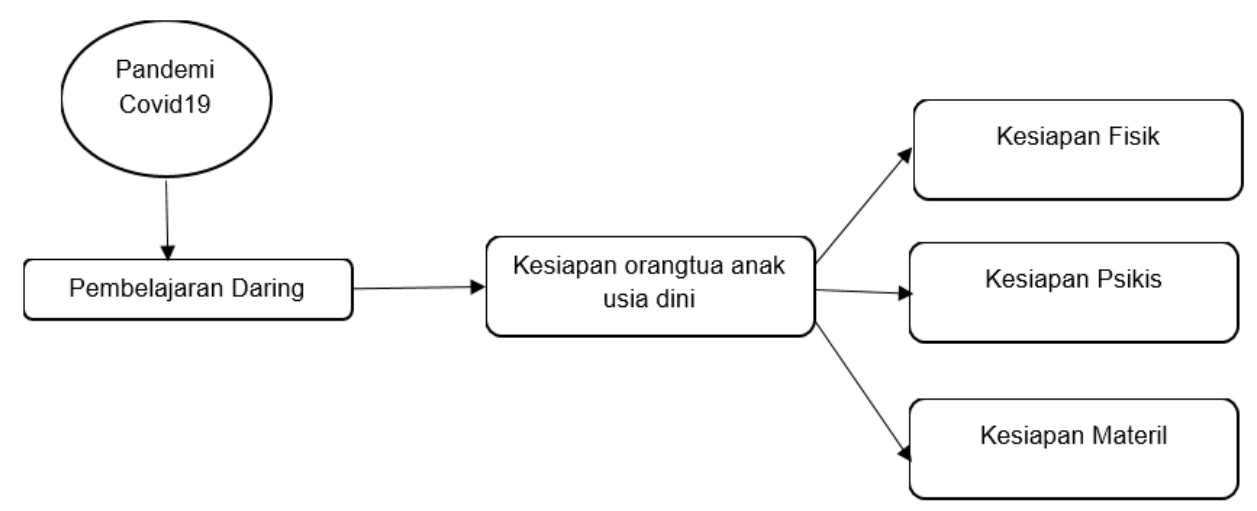

Gambar 1. Desain Penelitian

(Borotis \& Poulymenakou, 2004)

Responden dalam penelitian ini yaitu orang tua dalam langkah pembelajaran remaja berbasis online di Kota Denpasar. Berdasarkan perhitungan kuantitas pengujian menggunakan persamaan Slovin dengan tingkat akurasi 5\%, diperoleh contoh 390 responden.. Teknik Sampling yang digunakan adalah Corresponding Irregular Examining untuk mendapatkan pemeriksaan berdasarkan sub-kecamatan yang ada di Kota Denpasar, yaitu Kecamatan Denpasar Selatan, Kecamatan Denpasar Timur, Kecamatan Denpasar Barat, dan Kecamatan Denpasar Utara. Teknik pengumpulan informasi menggunakan survei menggunakan google form. Teknik survei akan memudahkan spesialis untuk mendapatkan informasi yang akan ditangani ditentukan untuk menangani masalah yang merupakan tujuan definitif dari suatu riset (Sugiyono, 2014). Kajian ini diarahkan pada riset yang random sampling, yang mengandung makna bahwa setiap populasi pemeriksaan sebagai komponen masyarakat memiliki kesempatan yang sama untuk menjadi contoh atau untuk menangani masyarakat dalam penyidikan survei akan disampaikan dan diisi melalui google form. Metode analisis informasi dipakai merupakan analisis deskriptif merupakan 
pengukuran yang memiliki tugas untuk memilah dan membedah informasi berupa angka (Ghozali, 2018). Memiliki pilihan untuk memberikan garis besar secara tepat, padat dan jelas, sehubungan dengan indikasi, kesempatan atau keadaan, dengan tujuan bahwa kesepakatan tertentu atau yang berarti dapat ditarik. Sebelum dilakukan analisis, kuisioner tersebut pertama kali diuji untuk validitas dengan validitas substansi Gregory, yang diperoleh bahwa survei memiliki validitas substansi yang tinggi. Tabel 1 adalah kisi-kisi survei yang digunakan dalam riset ini.

Tabel 1. Kisi-Kisi Kuesioner

\begin{tabular}{clcc}
\hline No & \multicolumn{1}{c}{ Pernyataan } & Skala & Skor Nilai \\
\hline 1 & Memiliki fisik yang sehat & Ordinal & $1-4$ \\
2 & Tidak mengalami gangguan pengelihatan & Ordinal & $1-4$ \\
3 & Dapat membagi waktu & Ordinal & $1-4$ \\
4 & Tidak mengalami kendala selama proses pembelajaran daring & Ordinal & $1-4$ \\
5 & Dapat ikut serta untuk berperan sebagai guru & Ordinal & $1-4$ \\
6 & Mampu berperan sebagai guru & Ordinal & $1-4$ \\
7 & Dapat menerima informasi dengan baik & Ordinal & $1-4$ \\
8 & Dapat memahami mengenai pertanyaan & Ordinal & $1-4$ \\
9 & Fokus mendampingi anak dalam proses pembelajaran daring & Ordinal & $1-4$ \\
10 & Dapat membimbing anak dalam mengerjakan tugas & Ordinal & $1-4$ \\
11 & Dapat mengumpulkan tugas anak dengan tepat waktu & Ordinal & $1-4$ \\
12 & Selalu memberikan arahan kepada anak & Ordinal & $1-4$ \\
13 & Memberikan motivasi & Ordinal & $1-4$ \\
14 & Mengingatkan anak & Ordinal & $1-4$ \\
15 & Tidak selalu memaksa anak untuk mengerjakan tugas & Ordinal & $1-4$ \\
16 & Tidak mengalami emosi saat mendampingi anak & Ordinal & $1-4$ \\
17 & Dapat memahami mengenai proses pembelajaran & Ordinal & $1-4$ \\
18 & Dapat menjelaskan kepada anak & Ordinal & $1-4$ \\
19 & Dapat bekerja sama dengan guru disekolah & Ordinal & $1-4$ \\
20 & Dapat menggunakan teknologi & Ordinal & $1-4$ \\
21 & Dapat memberikan saran kepada anak & Ordinal & $1-4$ \\
22 & Mampu memberikan pengetahuan ke anak & Ordinal & $1-4$ \\
23 & Dapat memahami mengenai pertanyaan yang diajukan oleh anak & Ordinal & $1-4$ \\
24 & Dapat memberikan respons dengan baik & Ordinal & $1-4$ \\
25 & Dapat memberikan media penunjuang & Ordinal & $1-4$ \\
26 & Memberikan buku-buku yang sesuai & Ordinal & $1-4$ \\
27 & Dapat memberikan fasilitas & Ordinal & $1-4$ \\
28 & Dapat meluangkan waktu & Ordinal & $1-4$ \\
29 & Memberikan tempat khusus & Ordinal & $1-4$ \\
30 & Dapat memberikan fasilitas yang lengkap & Ordinal & $1-4$ \\
\hline & & Djamarah \& Bahri, 2002$)$
\end{tabular}

Pada riset ini nilai deskriptif yang digunakan yaitu nilai rata-rata yang kemudian merujuk pada capaian persentase kesiapan orang tua. Kesiapan orang selanjutnya dijabarkan dalam 3 aspek yaitu kesiapan fisik, kesiapan psikis, dan kesiapan materil. Berikut ini adalah deskriptif yang digunakan berdasarkan nilai persentase ketercapaian indikator. Perhitungan tingkat pencapaian setiap pointer dinyatakan sebagai angka dengan menentukan skor terbaik sebelumnya. Mengklarifikasi kumpulan skor terbaik dengan anggapan bahwa setiap responden pada setiap pernyataan memberikan respon skor tertinggi, kemudian mengisolasi skor lengkap dengan skor terbaik. Standar yang digunakan dalam analisis persentase dalam riset ini mengacu pada likert's summeted rating (Sugiyono, 2012), sehingga diperoleh kategori seperti pada Tabel 2.

Tabel 2. Kriteria Persentase dengan Perhitungan Likert's Summeted Rating

\begin{tabular}{ccc}
\hline No & Koefisien Validitas & Keterangan \\
\hline 1 & $77,5 \% \leq \mathrm{P}$ & Sangat Positif \\
2 & $55,0 \% \leq \mathrm{P}<77,5 \%$ & Positif \\
3 & $50,0 \% \leq \mathrm{P}<32,5 \%$ & Kurang Positif \\
4 & $\mathrm{P}<32,5 \%$ & Tidak Positif \\
\hline
\end{tabular}




\section{Hasil dan Pembahasan}

Kesiapan orang tua secara keseluruhan diperoleh capaian persentase yaitu $75,24 \%$ yang mengartikan bahwa secara keseluruhan orang tua/wali pada proses pengajaran anak usia dini berbasis daring di Kota Denpasar, memiliki kesiapan yang cukup baik. pada umumnya orang tua memiliki kesiapan dalam pembelajaran daring namun tentunya dengan kendala-kendala yang dihadapi. Berikut ini adalah penjabaran dari hasil kuantitatif kesiapan orang orang tua dalam proses pembelajaran anak usia dini berbasis daring di Kota Denpasar. Kesiapan orang tua selanjutnya dijabarkan dalam 3 aspek yaitu kesiapan fisik, kesiapan psikis, dan kesiapan materil.

Tabel 3. Hasil Deskriptif Kesiapan Orang Tua

\begin{tabular}{|c|c|c|c|}
\hline No & Indikator & $\begin{array}{c}\text { Persentase } \\
\text { Rata-Rata }\end{array}$ & Kriteria \\
\hline 1 & $\begin{array}{l}\text { Kesiapan fisik orang tua akan berpengaruh terhadap } \\
\text { perkembangan belajar anak }\end{array}$ & $73.83 \%$ & Positif \\
\hline 2 & $\begin{array}{l}\text { Orang tua siap untuk memberikan dampingan kepada anak dalam } \\
\text { proses pembelajaran daring }\end{array}$ & $75.19 \%$ & Positif \\
\hline 3 & $\begin{array}{l}\text { Orang tua diharapkan untuk memiliki dasar dalam berperan } \\
\text { menjadi guru dimasa pandemi ini }\end{array}$ & $77.24 \%$ & Positif \\
\hline 4 & $\begin{array}{l}\text { Orang tua dapat memahami mengenai tugas-tugas yang didapatkan } \\
\text { dari sekolah }\end{array}$ & $79.42 \%$ & Positif \\
\hline 5 & $\begin{array}{l}\text { Orang tua memiliki kesehatan fisik yang optimal dalam } \\
\text { membimbing anak }\end{array}$ & $67.34 \%$ & Kurang Positif \\
\hline \multirow[t]{2}{*}{6} & Orang tua selalu ada selama proses pembelajaran daring & $75.62 \%$ & Positif \\
\hline & $\begin{array}{c}\text { Persentase rerata kesiapan fisik orang tua dalam proses } \\
\text { pembelajaran anak usia dini berbasis daring }\end{array}$ & $\mathbf{7 4 . 7 7 \%}$ & Positif \\
\hline No & Indikator & $\begin{array}{c}\text { Persentase } \\
\text { Rata-Rata }\end{array}$ & Kriteria \\
\hline 1 & $\begin{array}{l}\text { Kesiapan psikis orang tua akan berpengaruh terhadap proses } \\
\text { pembelajaran anak sehingga orang tua diharapkan dapat } \\
\text { memberikan arahan kepada anak. }\end{array}$ & $80.42 \%$ & Positif \\
\hline 2 & $\begin{array}{l}\text { Kesiapan psikis orang tua terganggu sehingga akan berpengaruh } \\
\text { terhadap kesiapan psikis anak. }\end{array}$ & $71.23 \%$ & Positif \\
\hline 3 & $\begin{array}{l}\text { Orang tua dapat memahami dan membantu anak dalam } \\
\text { mengerjakan tugas yang diberikan oleh guru. }\end{array}$ & $78.47 \%$ & Positif \\
\hline 4 & $\begin{array}{l}\text { Orang tua dapat menggunakan teknologi dalam proses } \\
\text { pembelajaran daring untuk berkomunikasi dengan guru. }\end{array}$ & $79.09 \%$ & Positif \\
\hline 5 & $\begin{array}{l}\text { Orang tua memiliki wawasan yang luas sehingga dapat } \\
\text { memberikan pengetahuan ke anak. }\end{array}$ & $77.56 \%$ & Positif \\
\hline \multirow[t]{2}{*}{6} & $\begin{array}{l}\text { Orang tua dapat memberikan respons/jawaban kepada anak dalam } \\
\text { proses pembelajaran daring. }\end{array}$ & $68.73 \%$ & Kurang Positif \\
\hline & $\begin{array}{c}\text { Persentase rerata kesiapan psikis orang tua dalam proses } \\
\text { pembelajaran anak usia dini berbasis daring }\end{array}$ & $75.92 \%$ & Positif \\
\hline No & Indikator & $\begin{array}{c}\text { Persentase } \\
\text { Rata-Rata }\end{array}$ & Kriteria \\
\hline 1 & $\begin{array}{l}\text { Orang tua dapat memberikan media pembelajaran yang akan } \\
\text { menunjang proses pembelajaran anak dirumah. }\end{array}$ & $76.49 \%$ & Positif \\
\hline 2 & $\begin{array}{l}\text { Kesiapan orang tua memfasilitasi anak dalam proses pembelajaran } \\
\text { daring. }\end{array}$ & $74.71 \%$ & Positif \\
\hline 3 & $\begin{array}{l}\text { Orang tua diharapkan untuk dapat memberikan suasana belajar } \\
\text { yang nyaman kepada anak. }\end{array}$ & $73.93 \%$ & Positif \\
\hline & $\begin{array}{c}\text { Persentase rerata kesiapan materil orang tua dalam proses } \\
\text { pembelajaran anak usia dini berbasis daring }\end{array}$ & $75.04 \%$ & Positif \\
\hline & Kesiapan Orang Tua Secara Keseluruhan & $75.24 \%$ & Positif \\
\hline
\end{tabular}

Persiapan fisik yang sebenarnya erat kaitannya dengan kesejahteraan yang akan mempengaruhi hasil belajar anak. Orang tua dapat dikatakan memiliki kesiapan fisik jika dapat mempengaruhi kelancaran dalam proses belajar anak (Djamarah \& Bahri, 2002). Orang tua yang memiliki gangguan 
terhadap kesiapan fisik disebabkan oleh kurangnya asupan vitamin, yang mengakibatkan kurangnya energi seperti gangguan lesu, mengantuk, dan sebagainya sehingga proses pembelajaran anak menjadi terhambat. Kesiapan fisik merupakan kemampuan orang tua untuk membimbing anak dalam ukuran pembelajaran berbasis online (Jamilah, 2020; Warliani \& Fauziyyah, 2020). Persiapan dari orang tua sangat penting sebagai dasar untuk mendampingi anak dalam proses pembelajaran, bila orang tua tidak memiliki kesiapan fisik maka proses pembelajaran anak tidak akan maksimal (Cahyono et al., 2021). Kesiapan fisik yang harus dimiliki oleh orang tua yaitu meliputi keseluruhan kondisi yang sehat sehingga dapat membuat anak menjadi siap untuk belajar sehingga anak dapat memberikan respon/jawaban serta memperoleh pengetahuan. Indikator yang diukur dari kesiapan fisik yaitu kesiapan fisik orang tua mempengaruhi kemajuan belajar anak. Orang tua siap membantu anak-anak mereka dalam ukuran pembelajaran berbasis online. Orang tua diharapkan untuk memiliki dasar dalam berperan menjadi guru dimasa pandemi ini. Orang tua dapat memahami tugas-tugas yang didapatkan dari sekolah. Orang tua memiliki kesehatan fisik yang optimal dalam membimbing anak dan orang tua selalu ada selama proses pembelajaran daring.

Pada indikator pertama, indikator kesiapan fisik orang tua dalam ukuran pembelajaran remaja berbasis online, khususnya ketersediaan orang tua yang sebenarnya akan mempengaruhi kemajuan belajar anak tersebut, diperoleh persentase rerata indikator tersebut sebesar 73,83\% yang kemudian masuk pada kriteria positif. Hal ini menggambarkan bahwa kesiapan fisik pada indikator perkembangan anak sudah baik. Indikator dimensi yang kedua, indiaktor orang tua siap untuk memberikan dampingan kepada anak dalam proses pembelajaran daring, diperoleh hasil persentase rerata indikator tersebut sebesar $75,19 \%$ yang kemudian masuk kriteria positif. Hal ini menggambarkan bahwa kesiapan fisik pada indikator pendampingan sudah baik. Pada umumnya orang tua akan terus mendampingi anak dalam kegiatan belajar daring walaupun kesibukan orang tua dirumah (Widyastuti et al., 2021; Yulianingsih et al., 2020). Hal ini dikarenakan orang tua ingin memastikan bahwa kegiatan pembelajaran belajar maksimal.

Indikator dimensi yang ketiga, indikator orang tua diharapkan untuk memiliki dasar dalam berperan menjadi guru dimasa pandemi ini, diperoleh hasil persentase rerata indikator tersebut sebesar 77,24\%yang kemudian masuk pada kriteria positif. Hal ini menggambarkan bahwa kesiapan fisik pada indikator memiliki dasar dalam berperan menjadi guru sudah baik. Hasil ini menunjukkan bahwa orang tua siap untuk memberikan bimbingan kepada anak-anak mereka dalam belajar daring. Adanya kondisi pandemi membuat orang tua harus siap dengan kondisi yang ada. Indikator dimensi yang keempat, indikator orang tua dapat memahami mengenai tugas-tugas yang didapatkan dari sekolah, diperoleh hasil persentase rerata indikator tersebut sebesar 79,42\%yang kemudian masuk pada kriteria positif. Hal ini menggambarkan bahwa kesiapan fisik pada indikator memahami mengenai tugas-tugas yang didapatkan dari sekolah sudah baik. Pekerjaan orang tua sebagai instruktur di rumah mewakili kapasitas orang tua untuk paham mengenai tugasnya (Kurniati et al., 2020; Yulianingsih et al., 2020). Ini jelas juga dilengkapi dengan koordinasi yang baik antara instruktur dan orang tua sama seperti siswa bersangkutan.

Indikator dimensi yang kelima, indikator orang tua memiliki kesehatan fisik yang optimal dalam membimbing anak, diperoleh hasil persentase rerata indikator tersebut sebesar 67,34\%yang kemudian masuk pada kriteria kurang positif. Hal ini menggambarkan bahwa kesiapan fisik pada indikator kesehatan fisik yang optimal sudah baik. Kondisi fisik orang tua yang optimal dikarenakan pada umumnya pepmbelajaran daring tidak terlalu lama dan orang tua dapat berganti peran dengan pasangannya. Indikator dimensi yang keenam, indiaktor orang tua selalu ada dalam proses pembelajaran daring, diperoleh hasil persentase rerata indikator tersebut sebesar $75,62 \%$ yang kemudian masuk pada kriteria positif. Hal ini menggambarkan bahwa kesiapan fisik pada indikator selalu ada dalam proses pembelajaran sudah baik. Orang tua selaku penanggungjawab anak di rumah tentunya akan selalu mengawasi anak dalam setiap kegiatan pembelajaran daring sehingga proses belajar mengajar dapat maksimal(Dewi \& Khotimah, 2020; Yulianingsih et al., 2020).

Ketersediaan psikis diidentifikasi dengan pengetahuan, memori tinggi, kebutuhan belajar anak yang terpenuhi, dan orang tua dapat memberikan motivasi serta perhatiankepada anak untuk belajar, sehinga anak dapat berkonsentrasi. Kesiapan psikis orang tua sangat penting karena sangat berpengaruh terhadap motivasi belajar dan memberikan arahan di dalam proses pembelajaran daring dan Kesiapan psikis adalah kecakapan dalam memahami dan membimbing anak sesuai dengan pelaksanaan pembelajaran daring. Dalam ukuran pembelajaran online, orang tua siap untuk pergi bersama anakanaknya untuk belajar dari rumah dan bekerja sama dengan guru disekolah sehingga terjalin komunikasi yang baik untuk mengetahui perkembangan anak belajar di rumah. Kerjasama yang terjalin dapat meliputi kesiapan orang tua dalam menerima dan mengumpulkan tugas anak melalui WhatsApp group, Zoom, atau Google Meet. Hal tersebut membuat orang tua jadi lebih bisa menyesuaikan diri dengan proses pembelajaran daring. 
Pada indikator pertama, indikator kesiapan psikis orang tua dalam ukuran pembelajaran remaja berbasis online utama, lebih spesifik ketersediaan mental orang tua, itu akan mempengaruhi kemajuan belajar anak, diperoleh persentase rerata indikator tersebut sebesar 80,42\% yang masuk pada kriteria positif. Indikator dimensi yang kedua, indikator kesiapan psikis orang tua terganggu sehingga akan berpengaruh terhadap kesiapan psikis anak, diperoleh hasil persentase rerata indikator tersebut sebesar 71,23\%yang masuk pada kriteria positif. Indikator dimensi yang ketiga, indikatororang tua dapat memahami dan membantu anak dalam menyelesaikan tugas yang diberikan oleh pendidik, diperoleh hasil persentase rerata indikator tersebut sebesar 78,47\%yang masuk pada kriteria positif. Pada umumnya orang tua mampu menerjemahkan pembelajaran daring dari guru kepada anak. Indikator dimensi yang keempat, indikator orang tua dapat menggunakan teknologi dalam proses pembelajaran daring untuk berkomunikasi dengan guru, diperoleh hasil persentase rerata indikator tersebut sebesar 79,09\%yang masuk pada kriteria positif. Pada umumnya orang tua sudah dapat mengoperasikan media pembelajaran daring sehingga proses pembelajaran dapat berjalan lancar.

Indikator dimensi yang kelima, indikator orang tua memiliki wawasan yang luas sehingga dapat memberikan pengetahuan ke anak, diperoleh hasil persentase rerata indikator tersebut sebesar 77,56\% yang masuk pada kriteria positif. Pada umumnya orang tua memiliki pengetahuan yang cukup baik dan dapat menjelaskan materi kepada anak berdasarkan apa yang diberikan guru. Indikator dimensi yang keenam, indikator orang tua dapat memberikan respon/jawaban kepada anak dalam pembelajaran daring, diperoleh hasil persentase rerata indikator tersebut sebesar 68,73\% yang masuk padakriteria kurang positif. Pada indikator ini menggambarkan bahwa orang tua dengan pengetahuan yang dimilikinya mampu menjawab pertanyaan dan memberikan penjelasan kepada siswa. Kesiapan psikis merupakan kesiapan dalam pembelajaran berupa materi tersebut tentunya harus memiliki bahan-bahan yang dapat direnungkan atau ditangani, misalnya buku-buku pemahaman, bacaan-bacaan pelajaran dari sekolah atau buku-buku terkait yang digunakan sebagai bahan referensi belajar anak, memiliki jurnal, dan sebagainya. Didukung oleh berbagai sumber pemahaman, akan memberikan informasi dan akan membantu anak-anak dalam belajar proses pembelajaran, dan dalam proses pembelajaran daring kesiapan materil meliputi gadget, kuota, dan komputer sebagai penunjang kelancaran anak dalam proses pembelajaran daring. Orang tua memberikan fasilitas seperti kondisi belajar yang nyaman untuk anak berupa tempat, suasana dan waktu belajar sehingga pembelajaran dapat berjalan dengan efektif.

Pada indikator pertama, indikator kesiapan materil dari orang tua pada langkah pendidikan anak usia dini berbasis online yang pertama yakni Orang tua dapat memberikan media pembelajaran yang akan menunjang anak dirumah,diperoleh persentase rerata indikator tersebut sebesar76,49\%yang kemudian masuk pada kriteria positif. Indikator dimensi yang kedua yakni kesiapan orang tua memfasilitasi anak dalam proses pembelajaran daring, diperoleh hasil persentase rerata indikator tersebut sebesar 74,71\%yang kemudian masuk pada kriteria positif. Proses kegiatan belajar mengajar secara daring tentunya membuat orang tua harus memberikan fasilitas kepada anak untuk memastikan kegiatan belajar mengajar berjalan dengan baik. Indikator dimensi yang ketiga yakni orang tua diharapkan untuk dapat memberikan suasana belajar yang nyaman kepada anak, diperoleh hasil persentase rerata indikator tersebut sebesar 73,93\% yang kemudian masuk pada kriteria positif. Proses pembelajaran yang dilakukan dirumah tentunya memberikan kenyamanan bagi anak.

Orang tua memiliki kesiapan yang baik dalam ukuran pembelajaran remaja berbasis online. Mengingat perhitungan semua penanda pada elemen persiapan aktual, tingkat normal adalah $74,77 \%$. Hasilnya kemudian diubah menjadi tabel ukuran laju yang diingat untuk standar positif. Orang tua telah mengambil bagian dalam pembelajaran online. Sebagian besar responden berpendapat bahwa pergi bersama anaknya saat belajar merupakan suatu kegiatan hal itu harus dilakukan dengan alasan bahwa anak benar-benar membutuhkan kursus dan manajemen dalam melakukan kewajiban pendidik, sehingga sebagian besar orang tua dapat menemani anak selama pembelajaran berbasis daring. Kesiapan orang tua yang sebenarnya akan memberikan efek yang baik ketika membantu anak-anak dalam langkah pembelajaran internet selama pandemi Coronavirus ini, karena anak-anak akan mengalami hambatan dalam memahami pemblajaran yang diberikan oleh pendidik. Selama siklus belajar daring berlangsung maka sangat diperlukan kesiapan fisik orang tua agar dapat memberikan bimbingan atau dampingan kepada anak selama proses pembelajaran daring (Wardani \& Ayriza, 2020).

Berdasarkan hasil perhitungan seluruh indikator pada dimensi kesiapan psikis, diperoleh persentase rerata sebesar 75,92\%. Hasil tersebut kemudian dikonversi ke tabel kriteria persentase yang masuk pada kriteria positif. Hal ini menunjukkan bahwa aksesibilitas wali dalam langkah-langkah pembelajaran berbasis online untuk pengaturan mental remaja jelas ditanggapi oleh semua orang tua yang menjadi responden dalam pemeriksaan ini. Kesiapan mental dapat dilihat dari toleransi wali dalam mengarahkan anak-anaknya dalam langkah pembelajaran online. Berdasarkan hasil perhitungan seluruh indikator pada dimensi kesiapan materil, diperoleh persentase rerata sebesar 75,04\%. Hasil tersebut 
kemudian dikonversi ke tabel kriteria persentase yang masuk pada kriteria positif. Hal ini menunjukan bahwa persiapan orang tua pada langkah-langkah pembelajaran berbasis online untuk anak usia dini, materi ditanggapi secara tegas oleh semua orang tua yang menjadi responden dalam ujian ini. Kerangka pembelajaran online tidak sesukses kerangka dekat dan pribadi. Mengingat di tengah krisis seperti saat ini, banyak hal yang harus diatur dengan baik agar interaksi belajar dapat berjalan dengan baik. Misalnya, yayasan, misalnya, organisasi web yang memadai. Pembelajaran berbasis web, tidak semua wali dapat mengoperasikan perangkat dengan alasan masih ada beberapa wali yang kondisinya belum cakap berinovasi. Wali memiliki dominasi inovasi yang rendah saat pembelajaran online (Karnawati \& Mardiharto, 2020). Pencegahan paling dikenal luas yang dialami dalam pembelajaran berbasis daring. Tetapi ketika orang tua memberikan dukungan yang baik dan memiliki kesiapan materil maka proses pembelajaran daring akan berjalan dengan baik, namun sebagian besar orang tua bersusaha untuk mengoptimalkan proses pembelajaran daring ini dengan memberikan fasilitas yang mendukung untuk kelancaran pembelajaran daring ini agar anak dapat mengikuti proses pembelajaran daring.

Kesiapan merupakan suatu kondisi yang digerakkan oleh individu dalam mengatur dirinya baik secara intelektual maupun secara nyata untuk mencapai sesuatu yang diinginkan (Ayuni et al., 2020). Persiapan adalah keadaan seseorang yang siap untuk memberikan reaksi dan respon, dan telah berkembang dalam perencanaan dirinya dan segala jenis kebutuhan yang diidentifikasi dengan status wali untuk memberikan bantuan interaksi belajar anak. Ketersediaan orang tua dalam interaksi pembelajaran sangat membutuhkan status mental dan aktual dalam pembelajaran usia dini berbasis online. Orang tua memegang peranan vital dalam langkah pembelajaran online orang tua sebagai fasilitator, pembantu, pelatih atau instruktur, dalam pembelajaran berbasis online. Persiapan orang tua dalam membina etika anak sangat memberikan pengaruh dalam mendorong etika anak. (Jamilah, 2020).

Selain itu, pengajaran mandiri harus dimungkinkan dengan arahan orang tua, siswa di rumah harus diberikan pelatihan yang positif dan bermanfaat (Al Hakim, 2021). Dengan hadirnya perangkat komputerisasi yang sangat modern, pembelajaran di rumah seharusnya dapat dilakukan secara online tanpa harus bertemu secara dekat dan pribadi dengan instruktur dan teman. Kemajuan inovatif dapat menyederhanakan hidup dan lebih serbaguna(Indahini et al., 2018). Selanjutnya dalam rangka meningkatkan kerangka kerja ujian rumah agar berjalan dengan baik, diperlukan kantor dan pondasi pendukung yang besar, misalnya kantor web sebagai tempat belajar, kantor pembelajaran seperti PC atau HP, dan lainnya. Hal ini dapat diusulkan agar pembelajaran secara daring dapat terlaksana dengan baik dan lancer.

Penelitian ini dapat dimanfaatkan sebagai bahan kajian atau informasi tambahan untuk kemajuan penyidikan yang terkait dengan pengaturan wali dalam usaha pembelajaran berbasis online untuk anak. Penelitian ini juga memiliki manfaat untuk semua kelompok, terutama keluarga, guru, dan kepala sekolah. Keluarga sebagai individu yang paling dekat dengan anak-anak dapat mengarahkan, mengarahkan dan mendukung anak-anak dalam mengikuti pembelajaran berbasis daring. Terlebih lagi, akibat bagi pendidik sebagai pengajar tentunya harus lebih siap mengerjakan yang bersifat pembelajaran berbasis daring sehingga nantinya penyusunan, pelaksanaan dan penilaian pembelajaran online akan jauh lebih unggul dan siap memenuhi tujuan dari kegiatan berbasis jaringan (daring) yang telah diputuskan oleh pendidik. Kemudian, akibat dari itu kepala sekolah dituntut untuk memiliki pilihan untuk membuat strategi dan meningkatkan kerjasama antara sekolah sebagai lembaga pendidikan formal dan orang tua yang berperan dalam mengajar dengan santai sehingga energi kerjasama kedua pemain dalam mengajar siswa dapat berjalan ideal.

\section{Simpulan}

Persiapan orang tua pada proses belajar anak usia dini berbasis daring, memiliki kesiapan yang cukup baik. Kesiapan pada setiap dimensi kesiapan fisik, kesiapan psikis, dan kesiapan materil menunjukkan bahwa orang tua memiliki kesiapan yang baik. Keterbatasan penelitian ini yaitu hanya mengkaji persepsi kesiapan orang tua berdasarkan penilaian ibu dan ayah, sehingga penelitian selanjutnya dapat mengembangkan kembali dengan mengontraskan kesiapan pendampingan pembelajaran oleh kedua orang tua. Penelitian ini tidak mengkaji secara inferensial untuk menganalisis factor-faktor yang mempengaruhi kesiapan orang tua, sehingga peneliti selanjutnya dapat mengkaji lebih mendalam mengenai hal tersebut. Penelitian ini memberikan kontribusi bahwa tugas orang tua diperlukan dalam tindakan pengajaran dan pembelajaran sehingga orang tua dapat lebih mudah mendampingi anak saat belajar. 


\section{Daftar Rujukan}

Al Hakim, M. F. (2021). Peran guru dan orang tua: Tantangan dan solusi dalam pembelajaran daring pada masa pandemi COVID-19. Riwayat: Educational Journal of History and Humanities, 1(1), 23-32. http://jurnal.unsyiah.ac.id/riwayat/.

Arikunto, S. (2010). Prosedur Penelitian. Rineka cipta.

Ayuni, D., Marini, T., Fauziddin, M., \& Pahrul, Y. (2020). Kesiapan Guru TK Menghadapi Pembelajaran Daring Masa Pandemi Covid-19. Jurnal Obsesi : Jurnal Pendidikan Anak Usia Dini, 5(1), 414. https://doi.org/10.31004/obsesi.v5i1.579.

Borotis, S., \& Poulymenakou, A. (2004). ELearning Readiness Components: Key Issues to Consider Before Adopting eLearning Interventions. Paper presented at the E-Learn: World Conference on ELearning in Corporate, Government, Healthcare, and Higher Education 2004.

Cahyono, E., Susetyarini, E., \& Nurrohman, E. (2021). Hubungan Kesiapan Orang Tua dengan Kemampuan Psikomotorik Siswa dalam Pembelajaran Daring Dimasa Pandemi COVID-19. Jurnal Ilmu Pendidikan, 4(1), 19-26. https://doi.org/10.33366/ilg.v4i1.2453.

Dewi, P. A. S. C., \& Khotimah, H. (2020). Pola Asuh Orang Tua Pada Anak Di Masa Pandemi Covid-19. Seminar Nasional Sistem Informasi, 2433-2441.

Djamarah, \& Bahri, S. (2002). Rahasia Sukses Belajar. Rineka cipta.

Ghozali, I. (2018). Aplikasi Analisis Multivariate dengan Program IBM SPSS 25. Badan Penerbit Universitas Diponegoro.

Handayani, T. (2020). Peran Orang Tua Dalam Membimbing Anak Pada Pembelajaran Daring Di Desa Ngrapah Kecamatan Banyubiru Tahun Pelajaran 2019/2020. Institut Agama Islam Negeri Salatiga.

Indahini, R. S., Sulton, \& Husna, A. (2018). Pengembangan Multimedia Mobile Learning Pada Mata Pelajaran Simulasi Dan Komunikasi Digita Kelas X SMK. Jurnal Kajian Teknologi Pendidikan, 1(2), 141-148. http://journal2.um.ac.id/index.php/jktp/article/view/3730.

Jamilah, J. (2020). Kesiapan Orang Tua Dalam Pengelolaan Pendidikan Anak Usia Dini. Autentik: Jurnal Pengembangan Pendidikan Dasar, 3(2), 86-96. https://doi.org/10.36379/autentik.v3i2.37.

Jayawardana, H. B. . (2020). Identifikasi Kesulitan Guru Paud Di Masa Pandemi Covid-19 Dan Solusinya. PAUDIA: Jurnal Penelitian Dalam Bidang Pendidikan Anak Usia Dini, 9(2), 40-50. https://doi.org/10.26877/paudia.v9i2.6647.

Karnawati, \& Mardiharto. (2020). Sekolah Minggu Masa Pandemi Covid-19: Kendala, Solusi, Proyeksi. Jurnal STT Simpson.

Khasanah, M. (2021). Peran Orang Tua Dalam Pembelajaran Daring Anak Usia Dini Kelompok B Di RA Diponegoro 1 Kutawis Kecamatan Bukateja Kabupaten Purbalingga. Institut Agama Islam Negeri (IAIN).

Kurniati, E., Nur Alfaeni, D. K., \& Andriani, F. (2020). Analisis Peran Orang Tua dalam Mendampingi Anak di Masa Pandemi Covid-19. Jurnal Obsesi : Jurnal Pendidikan Anak Usia Dini, 5(1), 241. https://doi.org/10.31004/obsesi.v5i1.541.

Lilawati, A. (2020). Peran Orang Tua dalam Mendukung Kegiatan Pembelajaran di Rumah pada Masa Pandemi. Jurnal Obsesi: Jurnal Pendidikan Anak Usia Dini, 5(1), 549. https://doi.org/10.31004/obsesi.v5i1.630.

Mansyur, A. R. (2020). Dampak COVID-19 Terhadap Dinamika Pembelajaran Di Indonesia. Education and Learning Journal, 1(2), 113. https://doi.org/10.33096/eljour.v1i2.55.

Marom, K. (2020). Peran Orang Tua Dalam Membangun Motivasi Belajar Siswa Selama Pandemi Covid-19 $\mathrm{Di}$ Sd Islam Daarul Muwahidin Semarang. Webinar Series FIP, 28-35. http://conference.upgris.ac.id/index.php/wsfip/article/view/1313.

Nur Khalimah, S. (2020). Peran Orang Tua Dalam Pembelajaran Daring Di MI Darul Ulum Pedurungan Kota Semarang. Institute Agama Islam Negeri (IAIN) Salatiga.

Nurdin, N., \& Anhusadar, L. (2020). Efektivitas Pembelajaran Online Pendidik PAUD di Tengah Pandemi Covid 19. Jurnal Obsesi : Jurnal Pendidikan Anak Usia Dini, 5(1), 686-697. https://doi.org/10.31004/obsesi.v5i1.699.

Nurhasanah R. (2020). Pembelajaran Daring DI i Masa Pandemi Covid 19 Pada Kelompok B.5 TK Kemala Bhayangkari Bone. Educhild, 2(2), 58-67.

Ota, M. K., Djou, A. M. G., \& Numbah, F. F. (2021). Problematika Pembelajaran Daring Siswa Kelas Vii Smpn. Jurnal Pengabdian Masyarakat, 2(1), 74-81. https://doi.org/10.37478/mahajana.v2i1.769.

Robandi, D., \& Mudjiran, M. (2020). Dampak Pembelajaran Dari Masa Pandemi Covid-19 terhadap Motivasi Belajar Siswa SMP di Kota Bukittinggi. Jurnal Pendidikan Tambusai, 4(3), 3498-3502. https://doi.org/10.31004/jptam.v4i3.878.

Satriana, M., Buhari, M. R., Makmun, M., Maghfirah, F., Haryani, W., Wahyuningsih, T., Wardana, H., Sagita, A. D. N., Oktamarina, L., \& Bakar, A. A. (2021). Persepsi Guru PAUD terhadap Pembelajaran Online: 
Fenomena Masa Pandemi Covid-19. Jurnal Obsesi : Jurnal Pendidikan Anak Usia Dini, 6(1), 362-373. https://doi.org/10.31004/obsesi.v6i1.1353.

Sugiyono. (2012). Metode Penelitian Administrasi (Cetakan ke). Alfabeta.

Sugiyono, M. (2014). Educational Research Methods Quantitative, Qualitative Approach and R\&D. Bandung: Alfabeta.

Syafari, Y., \& Montessori, M. (2020). Analisis Pembelajaran Daring Terhadap Motivasi Belajar Dan Prestasi Belajar Siswa Dimasa Pandemi Covid-19. Jurnal Basicedu, 5(3), 1295-1303. https://doi.org/10.31004/basicedu.v5i3.872.

Wardani, A., \& Ayriza, Y. (2020). Analisis Kendala Orang Tua dalam Mendampingi Anak Belajar di Rumah Pada Masa Pandemi Covid-19. Jurnal Obsesi: Jurnal Pendidikan Anak Usia Dini, 5(1), 772. https://doi.org/10.31004/obsesi.v5i1.705.

Warliani, R., \& Fauziyyah, S. (2020). Kesiapan Orang Tua Dalam Mendukung Pembelajaran Di Masa Pandemi COVID-19. Jurnal Pendidikan UNIGA, 14(2), 372. https://doi.org/10.52434/jp.v14i2.1031.

Widyasari, Nurbaiti., Irawan, Bambang., Muzayana, A. (2020). Kesiapan Orang Tua Dalam Mendampingi Anak Pada Pembelajaran Matematika Berbasis Pembelajaran Jarak Jauh.

Widyastuti, Kurniawan, S. B., \& Rintayati, P. (2021). Keterlibatan orang tua dalam pembelajaran daring selama pandemi covid-19 di sekolah dasar. Didaktika Dwija Indria, 9(449).

Wijayanti, R. M., \& Fauziah, P. Y. (2020a). Perspektif dan Peran Orangtua dalam Program PJJ Masa Pandemi Covid-19 di PAUD. Jurnal Obsesi : Jurnal Pendidikan Anak Usia Dini, 5(2), 1304-1312. https://doi.org/10.31004/obsesi.v5i2.768.

Wijayanti, R. M., \& Fauziah, P. Y. (2020b). Perspektif dan Peran Orangtua dalam Program PJJ Masa Pandemi Covid-19 di PAUD. Jurnal Obsesi: Jurnal Pendidikan Anak Usia Dini, 5(2), 1304-1312. https://doi.org/10.31004/obsesi.v5i2.768.

Wisnu Budi Wijaya, I. K. (2019). Menanamkan Konsep Catur Paramita Pada Anak Usia Dini Di Lingkungan Keluarga Dan Sekolah. Pratama Widya: Jurnal Pendidikan Anak Usia Dini, 3(2), 41-46. https://doi.org/10.25078/pw.v3i2.737.

Yulianingsih, W., Suhanadji, S., Nugroho, R., \& Mustakim, M. (2020). Keterlibatan Orangtua dalam Pendampingan Belajar Anak selama Masa Pandemi Covid-19. Jurnal Obsesi : Jurnal Pendidikan Anak Usia Dini, 5(2), 1138-1150. https://doi.org/10.31004/obsesi.v5i2.740.

Yusuf, S. P. (2020). Partisipasi Orang Tua Terhadap Pendidikan Anak Selama Pembelajaran Daring. Sumber Intelektual Negeri Serumpun.

ZULFIKAR, Z. (2020). Rekonstruksi Pendidikan Keluarga Pada Masa Pandemi (Studi Pada Walimurid SMPI Al Hasanah Kota Bengkulu). Annizom, Vol. 5 No.(3), 123-130. https://ejournal.iainbengkulu.ac.id/index.php/annizom/article/view/3477. 